\title{
The Perfect
}

\section{Storm: Section}

\section{2, Mandatory}

Minimum Sentences

\section{and the Problem of the Unusual Case}

\section{Peter Sankoff *}

In Wolfgang Peterson's enjoyable 2000 film, The Perfect Storm, ${ }^{1}$ starring George Clooney and Mark Wahlberg as fisherman in a doomed struggle against Mother Nature, a wonderful scene shows a local weatherman/meteorologist, flushed with excitement, outlining the details of an incoming mega-storm to a member of the newsroom:

\footnotetext{
Oh my God. Just look at this! The remnants of Hurricane Grace are coming up from the South. And then there's this incredible low pressure system swooping down from Canada. On top of that, there's a high-pressure system blowing down off the Grand Banks. And all three of them are going to collide. I've never seen anything like this before. It's going to be the perfect storm.
}

Though it is impossible for dry constitutional discussion to match the thrills of crackling dialogue and the impressive special effects of a Hollywood blockbuster, there is little doubt that Canada's courtrooms are feeling the first throes of their own constitutional "perfect storm." Much like the Hollywood version, the storm is the product of several distinct forces and has caught some unaware. One thing is certain, however. When the storm settles, the constitutional landscape involving section 12-the right to be free of cruel and unusual punishment ${ }^{2}$-is unlikely to ever be the same.

The building blocks for this storm stem from three distinct elements. The first is the long-standing judicial approach to section 12 of the Charter, which requires courts to assess both the actual impact of a sentence on the person before the court, and the potential for that same sentence to impose cruel and unusual punishment on a "reasonable hypothetical" offender. The second force is a Conservative government armed with a mandate to get tough on crime, whose policies have enacted minimum mandatory sentences for a wide variety of offencessomething Canada has never previously experienced. Finally, the third element pushing storm clouds onto the horizon is a judgment of the Supreme Court that extinguished the possibility of using the controversial constitutional exemption remedy as a "safety valve" for legislation of this type, a decision that firmly established the likelihood of more confrontations on section 12 in the courts in years to come.

Two recent decisions from courts in Ontario signal that the storm is now quite clearly on the horizon. Like all storms, it is difficult to predict exactly how much damage will be wrought. What seems inevitable is that some aspect of the existing approach to section 12 claims is going to be revamped, or a number of the government's cherished mandatory minimum penalties are going to be struck down. The various doctrines that govern the approach to minimum mandatory sentences are getting more and more difficult to reconcile, and Canada's appellate courts will soon be forced to address the ramifications of three pressure systems colliding at once. 


\section{Background: Storm Clouds on the Horizon}

\section{a) Section 12 and reasonable hypothetical analysis}

Despite being the only Charter provision that focuses exclusively on the sentencing phase of a criminal proceeding, section 12 has made relatively little impact on the criminal justice system overall. Though early decisions exploring the provision suggested that the clause might be used as an effective constraint against a seemingly never-ending parliamentary trend to ramp up levels of imprisonment for offences of all types, its usefulness waned after a series of Supreme Court judgments watered down its utility in rather dramatic fashion. Many scholars now regard section 12 as a prohibition with "little vitality,"3 whose potential has been hampered by a judicial record of "retreat and timidity."

The initial optimism for section 12 stemmed from the Supreme Court's decision in $R v$ Smith, ${ }^{5}$ which considered the constitutional validity of the mandatory seven-year term of imprisonment for any person convicted of importing narcotics into Canada contrary to section 5(2) of the Narcotic Control Act. ${ }^{6}$ Ostensibly designed to discourage large-scale importers like the accused-who was convicted for importing $\$ 150,000$ worth of cocaine-the provision applied to anyone caught importing. As drafted, a "small-time" trafficker who brought a single marijuana cigarette across the border faced an automatic seven-year sentence.

The accused in Smith quickly recognized that his factual circumstances made it unlikely that the Supreme Court would find the penalty he faced to be "cruel and unusual." 7 To get around this problem, he argued that the statute nonetheless contravened the Charter in a broader sense, contending that its operation would result in cruel and unusual punishment to others, thus conflicting with section 52(1) of the Constitution Act, 1982 which states that any provision that is "inconsistent with the provisions of the Constitution is, to the extent of the inconsistency, of no force or effect." The argu- ment was attractively simple. It posited a broad interpretation of section 52(1), contending that consideration of a statute's constitutionality includes a general assessment of validity and not merely a narrow one focused on the facts of the case before the court. The accused essentially attempted to profit from the Narcotic Control Act's overbreadth. $^{8}$

A majority of the Court accepted the wisdom of this interpretive approach. ${ }^{9}$ Lamer J, as he then was, stated that "an analysis of s 5(2) [is required] in order to determine if the minimum has the effect of obliging the judge in certain cases to impose a cruel and unusual punishment." 10 This was the case even though the punishment "would not be cruel and unusual... for many, if not most conceivable cases." ${ }^{11} \mathrm{He}$ concluded that:

the offence of importing ... covers numerous
substances of varying degrees of dangerous-
ness and totally disregards the quantity of
the drug imported ... Thus, the law is such
that it is inevitable that, in some cases, a ver-
dict of guilt will lead to the imposition of a
term of imprisonment which will be grossly
disproportionate.

The majority went on to reject the contention that Crown discretion could be utilized as a means of avoiding unconstitutional applications. Writing on this point, Lamer J noted:

In its factum, the Crown alleged that such eventual violations could be and are in fact, avoided through the proper use of prosecutorial discretion to charge for a lesser offence.

In my view, the section cannot be salvaged by relying on the discretion of the prosecution not to apply the law in those cases where, in the opinion of the prosecution, its application would be a violation of the Charter. To do so would be to disregard totally section 52 of the Constitution Act, 1982 which provides that any law which is inconsistent with the Constitution is of no force or effect to the extent of the inconsistency and the courts are duty bound to make that pronouncement, not to delegate the avoidance of a violation to the prosecution or to anyone else for that matter. ${ }^{13}$

The impact of Smith was significant. No longer would accused persons with shaky factual 
claims automatically be faced with a minimum mandatory sentence. ${ }^{14}$ Rather than arguing the merits of their own client's entitlement to leniency, lawyers could point to hypothetical offenders who were more suitably placed. In any case where it could be shown that the mandatory operation of a statute conflicted with the Charter in at least one "reasonable hypothetical" situation, ${ }^{15}$ the impugned provision would have to be struck down as being inconsistent with the Charter. ${ }^{16}$

Excitement surrounding this decision was short-lived. In $R v$ Morrisey, ${ }^{17}$ a challenge to the minimum period of four years' imprisonment mandated for offences of criminal negligence involving the use of a firearm, ${ }^{18}$ the accused attempted to adopt the reasoning set out by the Supreme Court in Smith. Although the appellant conceded that the punishment imposed was not "cruel and unusual" in his circumstances, it would violate section 12 when applied to a hypothetical offender, perhaps a first-time, careless offender who accidentally-albeit negligently-discharged his or her firearm, killing another.

The Supreme Court disagreed. Writing for a majority of the Court, Gonthier J held that section 12 analysis required a constrained application of hypothetical analysis, one that only considered "imaginable circumstances which could commonly arise with a degree of generality appropriate to the particular offence." 19 Instead of considering reported cases of criminal negligence involving firearms that he believed could represent "marginal" cases or examples where the judgment might not have accurately detailed the facts in the case properly, Gonthier $\mathrm{J}$ found it more effective to construct hypothetical models that were likely to arise. Two general models were then defined: the first concerning an individual who kills another while "playing" with a firearm, the second involving a "hunting trip gone awry." In both scenarios, Gonthier J concluded that a four-year term of imprisonment would not be cruel and unusual punishment considering the gravity of the offence and the need for denunciation and retribution.

Morrisey had a huge impact on section 12 challenges. Overnight, claimants could no lon- ger attack the validity of sentencing provisions by pointing to the overbreadth of an offence. In effect, Morrisey concluded that "unusual" scenarios should only be addressed in the event they actually made it to court. As a consequence, the Supreme Court appeared to endorse a proposition it had previously eschewed: that the proper use of Crown discretion, namely not bringing charges against people who "technically" fell within the confines of the offence, could suffice to address constitutional weaknesses with sentencing legislation that had the potential to affect at least one person in a manner that conflicted with section $12 .^{20}$

The result was a decline in the use of reasonable hypothetical analysis and challenges to the sentencing provisions on the books. Without a sympathetic fact scenario, counsel became unable to get past Morrisey's requirement that the provision had a likelihood of affecting persons in an unconstitutional way in the regular course of events. ${ }^{21}$ Moreover, at the time Morrisey was decided, mandatory sentencing provisions applied to only a small proportion of Criminal Code offences, and it was realistically possible that the decision to defer problematic examples to undefined future challenges would de facto resolve any constitutional deficiencies with Canada's sentencing legislation. In effect, section 12 challenges would become more a matter of historical significance than an ongoing problem for the judiciary.

\section{b) The rise of minimum mandatory sentences}

Had matters stopped there, the use of section 12 to challenge minimum mandatory sentences might well have died on the vine. Nonetheless, just as the Supreme Court was retreating from its formerly vibrant approach to section 12, Parliament was in the midst of developing a new love for minimum penalties. ${ }^{22}$ Bolstered by a Conservative Party advancing a "law and order" agenda, minimum mandatory sentences suddenly became an important part of the Criminal Code. Consider the fact that in 2000, when Morrisey was decided, there were only a handful of minimum mandatory penalties involving imprisonment in the Code, and most related to extremely serious crimes like murder 
or offences involving significant harm caused by a firearm By 2005 however, mandatory sentences of imprisonment had been enacted for twenty-nine offences, ${ }^{23}$ and there are now at least forty. ${ }^{24}$

The new offences have sparked a host of new constitutional challenges. Faced with mandatory minimum penalties for a variety of crimes, and with no other real hope of avoiding significant jail terms, offenders have begun turning back to section 12 in hope that courts will reengage with these issues anew.

\section{c) The end of constitutional exemptions}

As the two aforementioned developments were occurring, a third factor loomed as an important wild card in the clash between section 12 and mandatory minimum sentencing legislation. Drawing upon dicta from several Supreme Court of Canada decisions, a number of trial and appellate courts began turning away from the all or nothing solution to the overbreadth of mandatory sentencing provisions that had been suggested by Smith. Instead, they addressed unusual cases through use of a controversial remedy: the constitutional exemption, which permits a court to avoid striking down a piece of legislation where such legislation has an unconstitutional impact in rare instances. Rather than invalidating the offending statute in its entirety, the remedy is instead granted on a caseby-case basis to the particular applicant who can demonstrate that he or she is affected by the statute in an unconstitutional manner.

Exemptions have positive and negative facets, ${ }^{25}$ but their importance to the question of how to approach unusual cases should be obvious. In a 2003 article on the topic, I opined that:

As some judges have suggested, the exemption functions on the notion that the legislation in question is "constitutional in its general application." If this is the case, why should a court consider factual situations that do not arise in the action before it when they are only likely to apply in rare instances? So long as the statute is generally sound, it seems sensible to leave unusual applications to a future case where they can be remedied via a constitutional exemption. Obviously, this change in approach could seriously impede an accused person's standing to challenge existing legislation. No longer will it be possible to assert a wide variety of "reasonable hypotheticals" in which legislation might have an unconstitutional effect. The court's reply to such a challenge would be straightforward: so long as the hypothetical in question is likely to occur only infrequently, there is no need to strike down the legislation and provide a "windfall" to the accused person raising the hypothetical. If need be, that hypothetical person could apply for a constitutional exemption. ${ }^{26}$

The constitutional exemption remedy has an unusual history. Despite never receiving the blessing of the Supreme Court, exemptions were embraced by five provincial appellate courts and the Federal Court of Appeal and used to uphold a host of sentencing provisions during a fifteen-year period between 1993 and 2008. ${ }^{27}$

In a somewhat surprising turn of events however, a unanimous Supreme Court of Canada soundly renounced the remedy in 2008. In $R v$ Ferguson ${ }^{28}$ the Supreme Court concluded that use of constitutional exemptions to alleviate "unusual" instances of unconstitutional effect was undesirable. Writing for the Court, McLachlin CJC concluded that:

In granting a constitutional exemption, a judge would be undermining Parliament's purpose in passing the legislation: to remove judicial discretion and to send a clear and unequivocal message to potential offenders that if they commit a certain offence, or commit it in a certain way, they will receive a sentence equal to or exceeding the mandatory minimum specified by Parliament. The discretion that a constitutional exemption would confer on judges would violate the letter of the law and undermine the message that animates it. ${ }^{29}$

Instead of affirming exemptions, McLachlin CJC suggested that any minimum mandatory sentence regime that resulted in even a single unconstitutional application had to be struck down in its entirety. ${ }^{30}$

The Ferguson decision added an important element to the debate over minimum sentences and section 12. It now seems clear that judges cannot simply deal with unusual scenarios by 
exempting them from the ordinary scheme. As we shall see below however, the decision raises a number of questions about what will occur in these types of cases, should they ever arise.

\section{The Storm Hits}

\section{a) Overview}

The combination of these three elements has, in fact, created a "perfect storm", that is making its way into Canadian courtrooms. We now have a section 12 analysis that only addresses common cases, a raft of new minimum sentencing provisions, and no way of remedying individually problematic applications short of striking down the statute.

Two recent decisions from the Superior Court of Ontario show how this is taking place. ${ }^{31}$ They demonstrate that judges are still feeling their way through the foggy weather.

\section{b) $R v N u r^{32}$}

In Nur, the accused pleaded guilty to one count of possessing a loaded prohibited firearm contrary to s 95(1) of the Criminal Code, one of a host of crimes to receive a minimum period of imprisonment through an omnibus Bill enacted in 2008. A hybrid offence, it is subject to a three-year mandatory minimum sentence where prosecuted on indictment, though there is no minimum if the Crown elects to proceed by summary conviction. The accused in Nur was prosecuted on indictment and, as a result, brought a Charter challenge against the minimum sentence. Though a number of interesting issues were raised in the case, ${ }^{33}$ I shall confine discussion to the primary question considered by the court: did the mandatory minimum sentence violate section 12 of the Charter?

Code J began his analysis by quickly dispensing with the notion that the accused's rights were personally violated by the statute, holding that a three year sentence was not "grossly disproportionate" in the circumstances. He noted, however, that "it is not difficult to construct numerous sympathetic hypotheticals wherein lawful and licensed possession briefly becomes unlawful and unlicensed possession." ${ }^{34} \mathrm{He}$ listed a host of situations where a person with no criminal record took brief possession of a family member's licensed firearm in relatively innocuous circumstances, or where a person inherited firearms and forgot to license them. He pointed out that offenders in these types of cases who fully admitted their mistake and pleaded guilty would be punished in a grossly disproportionate manner if sentenced to three years of imprisonment. ${ }^{35}$

This conclusion notwithstanding, Code J upheld the statute. He did so by deciding that any problems with section 12 were likely to be avoided by the use of Crown discretion. Though the hypothetical scenarios listed above were "reasonable," Code J found it unfathomable that situations of this nature would ever be prosecuted on indictment, concluding that the Crown would inevitably proceed with "sympathetic" cases of this type summarily. In response to the argument that Smith expressly forbade such an approach, Code J noted:

\footnotetext{
The discretion that Lamer J was referring to ... was not the statutory power of election that exists in the case at bar. Rather, Lamer J was referring to an extraordinary discretion "not to apply the law," that is, a discretion to charge an importer of narcotics with some other offence but "not with the offence that the person has really committed." The propriety of such exercises of discretion was open to question at the time... It is simply not a comparable discretion to the power to elect to proceed summarily, which is expressly provided for in s. 95 and which is a discretion "to apply the law" and to charge the actual offence that the accused "has really committed." 36
}

Though this conclusion resolved the case before him, Code J went on to mention that his approach "is not without risks or costs". In particular, he wondered what the consequence would be if the Crown ever chose to proceed with a sympathetic case by indictment, triggering the minimum penalty in the process. He recognized that "one unwise Crown election may end up invalidating Parliament's ... sentencing regime for all cases," ${ }^{37}$ but posited that this was not necessarily the case. Instead, the appropriate answer might be for the accused to bring a Charter motion "to review and judicially reverse 
the Crown's election, as a section 24(1) remedy ... due to the unfair and unconstitutional effects of proceeding by indictment." 38

\section{c) $R v$ Smickle ${ }^{39}$}

The case of $R v$ Smickle should be familiar to most, as it received widespread media coverage when released. ${ }^{40}$ On the facts as found by the trial judge, the accused, a first-time offender, was simply a person in the wrong place at the wrong time. One night, while visiting his cousin, he decided to borrow his cousin's loaded, illegal firearm, and take a series of self-portraits on his laptop computer. At that very moment, in perhaps the unluckiest moment ever, the police executed a search warrant targeting the accused's cousin, and caught the accused redhanded with a weapon in his hand. According to the trial judge, understating matters considerably, it was a "very foolish act" that resulted in charges under section 95(1) of the Code, the same offence addressed in Nur. The Crown proceeded on indictment and asked for the mandatory three-year sentence.

In contrast to Nur, it was unnecessary for Molloy J to consider any reasonable hypotheticals. Instead, she concluded that the mandatory penalty was unconstitutional in relation to $\mathrm{Mr}$. Smickle personally. In her view, the appropriate sentence-in the absence of the minimumwas a one-year sentence, to be served conditionally. A three-year sentence, which would place the accused in a federal penitentiary, would be a grossly disproportionate response, and, as a consequence, the accused's section 12 rights were violated by the mandatory minimum.

The truly difficult question was what to do next. Molloy J began by rejecting the option of reviewing the Crown's exercise of discretion as suggested by Code J in Nur:

First, the Crown discretion existed in this case and was exercised appropriately on the facts known to the Crown at the time. There is very little scope for judicial review of an exercise of Crown discretion and no possibility of reversing a decision made in good faith and in the valid exercise of that discretion. In this case, notwithstanding the supposed safety valve and the valid exercise of Crown discretion, I am faced with a legislative requirement to impose a sentence that would result in cruel and unusual punishment. In short, the safety valve does not always work, and did not work in this case. $^{41}$

Molloy J subsequently noted that a constitutional exemption was not available, and went on to adopt the only course left to her, striking down the statute. In effect, one problematic conviction spelled doom for the section. ${ }^{42}$

\section{Meteorological Analysis}

\section{a) How did we get here?}

It is not difficult to see how we have arrived in this position. Smickle and Nur are the logical result of the Supreme Court's decision in Morrisey to avoid deciding upon constitutional questions until they arise, and Parliament's refusal to leave wriggle room for exceptional cases. Leaving aside altogether the wisdom of using these types of penalty as a matter of policy, mandatory minimum sentencing provisions impose huge challenges for constitutional adjudication. No matter how constrained a court is in applying a reasonable hypothetical analysis, it is simply inevitable that real cases will eventually veer into section 12 territory. This stems from the fact that the substantive crimes in the Code are designed to be as all-embracing as possible, and in assigning culpability they make little distinction for important sentencing concerns like party liability, the degree of one's participation, the existence of pre-meditation, one's motivation, and whether or not the person involved is a first-time offender. This inevitably creates problems for any policy of minimum sentencing that is applied notwithstanding these differences. As Benjamin Berger has noted:

The essence of a minimum sentence is that it purports to know in advance the floor or proportionality for a given offence, irrespective of the specifics of the case. But life serves up circumstances far more complex and difficult than even the most prescient parliamentary committee can anticipate. Cases ... will find their way before sentencing judges [] in which exceptional circumstances make a minimum sentence so unfit as to unjustifiably offend the 
section 12 protection against cruel and unusual treatment or punishment. Although this is particularly true of crimes that cover broad ranges of behavior ... given the combined effects of time and the extraordinary vicissitudes of life, cases will arise that put pressure on any substantial minimum sentence tested against our constitutional commitments and fidelity to the morality of proportionality in sentencing. ${ }^{43}$

None of this is helped by Crown policies that seem to encourage prosecuting by indictment for many of the offences that possess minimum sentences. In Nur, for example, Code J made note of the fact that, in cases involving firearms, "the Crown Policy Manual in this province places significant constraints on the power to elect to proceed summarily." ${ }^{34}$

The result at present seems to be that section 12 litigation will continue to proceed in erratic fashion and certainty regarding the "permanence" of most of the minimum mandatory sentencing provisions will be hard to come by. The Supreme Court has effectively created a situation where, unwittingly or otherwise, challenges to these provisions may-depending on available fact scenarios-continue indefinitely. As I discuss below, decisions from higher courts will have limited precedential value as a result.

What is unfortunate about this sort of approach is that significant questions about mandatory minimums are unlikely to be addressed in future cases owing to the analytical framework that focuses more on the "unusual" nature of the offender than in the wisdom of Parliament's decision to enact a minimum sentence in the first place. Given that the majority of decisions will continue to focus on whether a particular case is or is not a "reasonable" hypothetical, or, in contrast, deal with the specific features of the accused's "unreasonable" facts, bigger issues about the advisability of mandatory minimums are likely to be lost in the shuffle. ${ }^{45} \mathrm{~A}$ number of critics have posed challenges to this approach to sentencing and, among other concerns, have questioned the way in which it has shifted the Canadian philosophy of sentencing altogether, reduced the importance of "proportionality" as a core principle in sentencing, and helped to ratchet up sentences handed out for a particular offence across the board. ${ }^{46}$ The current jurisprudential approach, with its primary focus on overbreadth, leaves questions of this type on the periphery of the constitutional discussion.

\section{b) Could opening the door to Crown dis- cretion resolve the problem?}

One of the more interesting aspects of the Nur decision lies in the way Code J raised the possibility of resolving certain section 12 challenges as potential abuses of prosecutorial discretion. Were it to be adopted, this approach would go a long way towards safeguarding mandatory sentencing provisions from being struck down under section 52 of the Constitution Act, 1982. If an unusual case arose, a breach of section 12 would target the Crown's decision to proceed indictably as an abuse of process, rather than the legislation itself. It is not entirely clear how abuses of this sort would be resolved, but one guesses that section 24(1) of the Charter would be invoked to quash the indictment and have the charges resolved in the summary jurisdiction, where no mandatory minimum sentence is required.

The idea is intriguing. It would operate much like a constitutional exemption, treating unusual cases on their own merits. In the process, it would safeguard the constitutionality of the statute, and ensure that properly constructed mandatory minimums with laudable objectives withstood Charter challenges. It would also simplify the section 12 analysis and guarantee the "precedential" value of Charter decisions rendered under this provision. There would no longer be a need to consider the actual facts of a given case in deciding whether a sentencing provision was constitutionally sound. Section 12 challenges to the legislation would be based solely on reasonable hypothetical analysis or by assessing the larger merits of minimums, as discussed above. Once resolved, the constitutionality of the statute would be ensured. ${ }^{47}$ In effect, one decision from the Supreme Court of Canada regarding a sentencing provision would be binding on future challenges to the legislation. Individual cases would have to proceed by claiming an abuse of process. 
Despite these "advantages," it is difficult to imagine this course being adopted. To begin with, notwithstanding Code J's clever attempt to distinguish Smith, his approach ignores the fact that the Supreme Court's distaste for the suggestion that Crown discretion can salvage imperfect legislation goes well beyond Lamer J's comments on the topic in Smith. For example, in $R v$ Bain, Cory $\mathrm{J}$ held for a majority of the Court that:

\footnotetext{
Unfortunately it would seem that whenever the Crown is granted statutory power that can be used abusively then, on occasion, it will indeed be used abusively. The protection of basic rights should not be dependent upon a reliance on the continuous exemplary conduct of the Crown, something that is impossible to monitor or control. Rather the offending statutory provision should be removed. ${ }^{48}$
}

More recently, the Ontario Court of Appeal in $R$ $v$ Levkovic $^{49}$ discussed the appropriateness of relying upon Crown discretion as a means of mitigating the potential overbreadth of a statute. In that case, the question was whether relying upon the Crown's discretion not to charge a person at all where certain trivial forms of activity might be caught by a statute could obviate that legislation's unconstitutional impact. Following a long line of precedent, the Court of Appeal concluded that this approach was not available, Watt JA noting that:

A claim of unconstitutionality, whether advanced as vagueness, overbreadth or otherwise, is not answered by reliance on prosecutorial or judicial discretion to confine its application: R. v. Nguyen; R. v. Hess, [1990] 2 S.C.R. 906, at p. 924; Lavallee Rackel \& Heintz v. Canada (Attorney General); White, Ottenheimer \& Baker v. Canada (Attorney General); R. v. Fink, [2002] 3 S.C.R. 209, at para. 45; R. v. Bain, [1992] 1 S.C.R. 91, at pp. 103-104. ${ }^{50}$

This reasoning seems directly applicable to Nur, as it affirms that it is inappropriate to leave a statute in place on the basis that the Crown could be trusted not to charge people if it would have an unconstitutional impact on the person being charged. Yet in Nur, Code J concluded that constitutional difficulties could be avoided by relying on the Crown to charge the person correctly.
There are practical concerns as well. Code J himself noted that "Crown elections to proceed summarily or by indictment are usually made at an early stage of proceedings, when the Crown is not always in possession of all the facts." ${ }^{1}$ The traditional focus of the abuse of process inquiry exacerbates this concern. On this point, the case of Mohla, ${ }^{52}$ yet another recent decision of the Ontario Superior Court of Justice, is instructive. In Mohla, the accused was convicted of "operating a motor vehicle with an 'over .80' blood alcohol level," and had a previous conviction for a drinking and driving offence, albeit a dated one from $1998 .{ }^{53}$ The Crown nonetheless exercised its discretion under section 727(1) of the Code, notifying the accused that it would seek an increased penalty for the repeat conviction. Service of the notice triggered the application of section 255(1)(a)(ii) and the mandatory period of fourteen days imprisonment that went with it.

Rather than challenging the mandatory minimum, on the basis that it applied regardless of the "gap" between convictions, ${ }^{54}$ the accused challenged the Crown's decision to serve him with notice, alleging it to be an abuse of process. In a lengthy decision, Hill J rejected the claim, noting that the decision to serve notice was a "core element of prosecutorial discretion" and only subject to review where the discretion was exercised "arbitrarily, capriciously or for some improper motive." ${ }^{55}$ On this point, he held that:

Case-by-case supervision of the reasonableness of a prosecutor's exercise of discretion to prove the s. 727(1) notice, apart from its disabling impact on trial delay initiatives, would inevitably plunge the court into second-guessing the assessment of cases by Crown counsel within their public law function. Constitutional separation of powers would be eroded. ${ }^{56}$

If the decision to elect is treated in a similar manner, ${ }^{57}$ then it simply cannot be reviewed effectively. As the Supreme Court held in $R v$ Nixon, "it is not the role of the court to look behind a prosecutor's discretionary decision to see if it is justified or reasonable in itself.... [The court] only looks behind the decision for 'proof of the requisite prosecutorial misconduct, improper 
motive or bad faith in the approach'." 58

This simply would not function well for section 12 claims. For Code J's approach to be workable, a court's focus must be on the impact of the Crown's decision on the accused, and not why the Crown elected to proceed by indictment. As noted above, in many cases the Crown's decision at the time of charging will be both logical and reasonable. Only during the sentencing phase of trial will the particular facts of the accused perhaps change the nature of the equation. Focus on the Crown's motivations will ignore the accused's personal plight, and leave a valid section 12 claim unanswered. Simply put, treating these cases as an abuse of discretion is not a functional way of dealing with this problem. ${ }^{59}$

\section{c) Storm warnings}

Nur and Smickle are both attempts to deal with a fairly difficult situation. Given the difficulties with the "abuse of process" position and the unlikelihood of it being adopted, it seems clear that section 12 cases will continue to proceed in their current fashion, with sentencing provisions being challenged mostly when appropriate fact scenarios arise.

Moreover, the decision to focus on a narrow band of "reasonable hypothetical" scenarios when assessing the constitutionality of a statute means that a sentencing provision is effectively constitutional and only an appropriate case necessitates a re-assessment of the section 12 analysis. In Ferguson, the Court concluded as much, noting that "[i]n the absence of any provision providing for discretion, a court that concludes that a mandatory minimum sentence imposes cruel and unusual punishment in an exceptional case before it is compelled to declare the provision invalid." 60

Smickle would seem to be the first serious application of this doctrine, and, not surprisingly, the decision raises a number of new challenges the courts will have to address. Consider the following:

1. The Supreme Court's chosen approach to section 12 means that the precedential value of judgments in this area has diminished considerably. Even unanimous decisions of the Supreme Court are binding only insofar as the decision in question expressed an opinion on a reasonable hypothetical that matches the accused's individual circumstances; ${ }^{61}$

2. The need to reconsider the constitutionality of sentencing provisions in light of an existing precedent is bound to heighten pressure on judges at the trial stage. The balancing test of "gross disproportionality" is onerous enough and involves the consideration of various competing factors. One can only reckon that it will get tougher knowing that the continued existence of the law turns on a single set of facts; ${ }^{62}$

3. It is surprising that no one seems to have considered what should actually happen where a statute is invalidated under this approach. In other areas of constitutional litigation, the Supreme Court has repeatedly mentioned the importance of "dialogue" between Parliament and the courts, ${ }^{63}$ and the idea that defects in legislation can be remedied through careful drafting that takes into account shortfalls in the law. But how does that idea apply in this scenario? In most cases involving section 12 , a court will be declaring a law to be unconstitutional simply because of a single unusual application. Indeed, it is quite possible-indeed likely-that the statute will already have been upheld using reasonable hypothetical analysis. What can Parliament do at that stage? Can it re-enact the law in full? Or does it need to include a special exemption for "unusual cases?" Of course, if the latter avenue is the correct route to take, one has to wonder why the courts don't simply speed up the process by expanding the reasonable hypothetical analysis and requiring these exceptions as a matter of course.

Before leaving this section, it is worth taking one last look at Ferguson, as the Court's reasoning on exemptions leads to a few questions about the future of section 12 . In rejecting exemptions, McLachlin CJC made a number of comments that are worthy of further consideration: 


\begin{abstract}
Allowing unconstitutional laws to remain on the books deprives Parliament of certainty as to the constitutionality of the law in question and thus of the opportunity to remedy it. Legislatures need clear guidance from the courts as to what is constitutionally permissible and what must be done to remedy legislation that is found to be constitutionally infirm ... Bad law, fixed up on a case-by-case basis by the courts, does not accord with the role and responsibility of Parliament to enact constitutional laws for the people of Canada. ${ }^{64}$
\end{abstract}

It is an eloquent and forceful position, and a strong reason for rejecting case-by-case solutions to the unconstitutionality of legislation. But, with respect, it is impossible to read this and not recognize that the exact same criticism can be levied at the Court's current approach to reasonable hypotheticals. ${ }^{65}$ In contrast to other types of constitutional decision-making, it is virtually impossible to ever pronounce that a sentencing provision's fate is secure. By deferring tough decisions to a future occasion, Parliament is left with no guidance about how sound its legislation actually is. Moreover, the perennial failure to consider the core issue in section 12-whether it is a good idea to have mandatory sentencing provisions applied to an infinite range of circumstances-allows "bad law" to be fixed up on a case-by-case basis as judges weigh the merits of individual offenders bringing "unusual" circumstances to the fore. ${ }^{66}$

This hardly seems like a prudent or efficient way of dealing with mandatory minimums. Nor is it consistent. The vagaries of particular Crown decisions across the nation are ultimately going to decide which provisions die and which survive. While there are few easy answers here, there simply has to be a better way of proceeding than this.

\section{Conclusion}

As with any storm, it is difficult to know exactly what damage will be done to the landscape until the various forces collide. It seems inevitable that the problem of the "unusual case" is going to force the judiciary's hand at some stage. For decades, the Supreme Court has held firm to the notion that removal of judicial discretion where constitutional rights have the potential to be impacted is bound to cause difficulty in application. ${ }^{67}$ Leaving matters in the hands of individual Crown Attorneys and waiting for an appropriate case to defeat the statute hardly seems like the best way to proceed.

Finding a better answer does not exactly require deep genuflection. ${ }^{68}$ Parliament has already demonstrated through certain initiatives in the Criminal Code that it understands the risk posed by "unusual cases." Consider, for example, the DNA evidence collection procedures that are worded in mandatory language. Section 487.051(1)(a) of the Criminal Code currently provides that in the case of an offender being convicted of a "primary designated offence"69 a court shall order the collection of a DNA sample. ${ }^{70}$

It is difficult to dispute the need and utility of such a provision, which has made the investigation of criminal offences more effective on the whole. Moreover, in the vast majority of cases, there is little doubt that the taking of a sample is justified and reasonable. Nonetheless, there is a considerable jurisprudence explaining that a person has a right to privacy in his or her own genetic information, and that forced takings of such information must be reasonable. Given the breadth of offences covered by the legislation, and the infinite number of scenarios in which an offender might fall within the scope of the collection procedures, it stands to reason that there situations might in which a taking is, in fact, be unreasonable and, thus, unconstitutional.

Ferguson suggests that the solution in such a case is to strike down the section of the Criminal Code in its entirety. Leaving aside the merits of the Supreme Court's decision to ban exemptions as a valid remedy, is this really the best solution where a statute is constitutional in the overwhelming majority of cases? Thankfully, where DNA collection orders are concerned we do not have to consider this possibility, simply because the mandatory language of the collection procedure is made subject to a restricted discretion under subsection (2):

The court is not required to make an order 
under paragraph (1)(a) if it is satisfied that the person or young person has established that, were the order made, the impact on the person's or young person's privacy and security of the person would be grossly disproportionate to the public interest in the protection of society and the proper administration of justice, to be achieved through the early detection, arrest and conviction of offenders.

By inserting this clause, Parliament has virtually guaranteed the constitutionality of its primary legislation. It will, of course, still be open to an applicant to contest the legislation in its entirety, ${ }^{71}$ but the discretion restricts the ability to rely upon unusual fact scenarios and helps ensure that the legislation withstand challenge. It does this in two ways. First, it ensures that a "reasonable hypothetical" of particular discomfort to the judiciary cannot be used to demonstrate the overbreadth of the primary collection provision, ${ }^{72}$ as such a "worst-case" scenario, can be addressed by a discretionary exception. Second, assuming that the general validity of the scheme is viewed as being sound, it ensures that "actual" case scenarios which cause difficulty end up becoming challenges to the wording and structure of the discretion, rather than to the general provision. ${ }^{73}$

To be sure, enactment of this type of discretion means that the collection procedures are no longer universal. Nonetheless, given the language of the provision, it stands to reason that exceptions will be incredibly rare. The unusual nature of the exception can also be bolstered by a requirement to provide reasons and by providing the Crown with an automatic right to appeal. ${ }^{74}$ Philosophical objections aside, are exceptions of this type really a threat to the government's objectives?

My guess is that some who decry the rise of mandatory minimum penalties would be aghast at this development, feeling that it would undermine the development of section 12 jurisprudence and lead claims of this sort to be dealt with through the exception, with the result being that most mandatory minimums would remain in place. Berger, for example, sees Ferguson as a positive decision for section 12 , noting that the absence of an escape valve "improves on the distribution of responsibility for constitutional interpretation in the field of penal law," and by forcing judges to strike down legislation when faced with an exceptional case, "creates some structural pressure and the possibility for deeper legislative reflection on the justness of penal policy." 75

Though Berger's points have merit, I am not convinced that exceptional cases are the best way of causing this sort of legislative reflection. To begin with, there is little in the jurisprudence to indicate that the Supreme Court has any great enthusiasm for a crackdown on mandatory minimums. Ultimately, the long-term functionality of section 12 is going to rise or fall on the judiciary's willingness to look more broadly at the impact of minimum sentences and render judgments based on a need for proportionality, respect of the gap principle, concerns about arbitrariness or conflicts with other principles of fundamental justice. Overbreadth is an unwieldy tool and unlikely to ever provide a true check on sentencing, as it will always be open to Parliament to insert exceptions along the lines set out above. Moreover, decisions striking down legislation on the basis of overbreadth are likely to cause a reactionary outcry, as they shift the narrative away from the wisdom of minimum sentencing on the whole and toward a discussion about whether the judiciary is nitpicking in individual cases.

Finally, I am unconvinced that using overbreadth as a primary tool for challenge is an effective way of driving policy forward in the long-term. It is an erratic means of dealing with the issue, to put it mildly, and its application depends on errors by Crown Attorneys or unique factual matters arising in sentencing that were unknown when charges were laid. To be sure, this may cause prosecutors to reflect more carefully on charging decisions, but, by and large, all of this seems like a poor way of dealing with difficult questions of sentencing policy.

When this storm finally reaches the Supreme Court, there remains the possibility that the judges will recognize the failures that the existing analytical approach has created. In rejecting the seductive remedy of the constitutional exemption, the Court stressed a need for 
consistency and finality. One can only hope that the Court will see the wisdom of this approach in respect of section 12 as well, and re-address the mode of analysis that continues to dominate in that area.

\section{Notes}

* Professor, University of Alberta, Faculty of Law.

1 The Perfect Storm, 2000, DVD: (Burbank, Cal:

Warner Bros, 2000): http://www.imdb.com/title/ tt0177971/ [emphasis in original].

2 Canadian Charter of Rights and Freedoms, Part I of the Constitution Act, 1982, being Schedule B to the Canada Act, 1982 (UK), 1982, c 11, s 12 [Charter].

3 Jamie Cameron, "Fault and Punishment under Sections 7 \& 12 of the Charter" (2008) 40 Sup Ct L Rev (2d) 553 at 584. See also Kent Roach, "Searching for Smith: The Constitutionality of Mandatory Sentences" (2001) 39 Osgoode Hall LJ 367 at 411 [Roach] (approach to section 12 characterized by a "cautious form of constitutional minimalism and deference to Parliament" at 412); Allan Manson, "Arbitrary Disproportionality: A New Charter Standard for Measuring the Constitutionality of Mandatory Minimum Sentences" (2012) 57 Sup Ct L Rev (2d) 173 (suggesting that section 12 has become moribund; attacks on sentencing provisions should proceed through section 7) [Manson].

4 Don Stuart, Charter Justice in Canadian Criminal Law, 5th ed (Carswell: Toronto, 2010) at 497. Much of the criticism is driven by the high threshold required to show a constitutional breach, as the jurisprudence requires any sentence imposed to be "grossly disproportionate." I have no intention of discussing this aspect of section 12 here. This article assumes that the threshold can be met in some circumstances, and assesses what might occur when a sentence is in fact grossly disproportionate. For criticism of the section 12 standard, see Roach, supra note 3. [1987] 1 SCR 1045, 40 DLR (4th) 435 [Smith, cited to SCR].

6 RSC 1970, c N-1, s 5 (2).

7 Indeed, the Court unanimously concluded that the penalty with respect to the accused was not manifestly unreasonable.

8 In fairness, there is a strong argument to be made that the seven-year minimum also skewed the sentencing structure by forcing courts to impose higher sentences on more serious offenders: see Kent Roach, Constitutional Remedies, loose-leaf (consulted on 3 December 2012), (Canada Law Book: Toronto, 1997, ) ch 14 at 30-36.

9 The decision seemed to build upon the approach to constitutional litigation developed earlier in $R v$ Big M Drug Mart, [1985] 1 SCR 295, 18 DLR (4th) 321 [cited to SCR] at para 39, which had concluded that "any accused, whether corporate or individual, may defend a criminal charge by arguing that the law under which the charge is brought is constitutionally invalid."

10 Smith, supra note 5 at para 52 [Emphasis added].

11 Ibid at para 121, per Le Dain J.

12 Ibid at para 66.

13 Ibid at paras 68-69.

14 See Allan Manson, "Answering Some Questions About Cruel and Unusual Punishment” (1987) 58 CR (3rd) 247 at 250.

15 Clearly, this argument only functions where the operation of the statute is mandatory. Where a provision allows room for administrative or judicial discretion, an appellate Court will not consider hypotheticals and strike down a provision merely because there is a potential for some unconstitutional application. Rather, each exercise of discretion is reviewable for the purpose of ensuring it meets with Charter standards: Slaight Communications v Davidson, [1989] 1 SCR 1038.

16 Or some other appropriate remedy—such as severance or reading in-found.

17 [2000]2 SCR 90 [Morrisey]. See also $R v$ Goltz, [1991] 3 SCR 485; $R v$ Wiles, [2005] 3 SCR 895.

18 Criminal Code, s 220(a).

19 Morrisey, supra note 17 at para 50.

20 On this point, see also Roach, supra note 3 at 383-386, who suggested that the Court had adopted an American style "as applied" approach to constitutional review, and was critical of it.

21 Ibid at 385, noted that "the trend towards examining the effects of the penalty in the case at hand ... makes life more difficult for defence lawyers by forcing them to defend the injustice of applying the penalty to their particular offender."

22 The timing is probably not coincidental. In 2001 Roach speculated that the Supreme Court's decision in Morrisey "is ... likely to encourage Parliament to enact more mandatory minimum penalties," ibid at 411.

23 Federal Department of Justice, Mandatory Sentences of Imprisonment in Common Law Jurisdictions: Some Representative Models by Julian V Roberts, (Ottawa: Research and Statistics Division, 2005) at 9.

24 Don Stuart, Annotation to R v Smickle (2012) 91 CR (6th) 132 at 133. For further detail on the latest additions to the fold, and their political back- 
drop, see Benjamin L Berger, "A More Lasting Comfort? The Politics of Minimum Sentences, the Rule of Law and $R v$ Ferguson" (2009) 47 Sup Ct L Rev (2d) 101 at 105-109 [Berger].

See Peter Sankoff, "Constitutional Exemptions: Myth or Reality?” (1999-2000) 11 NJCL 411 [Sankoff].

26 Peter Sankoff, "Constitutional Exemptions: An Ongoing Problem in Need of a Swift Resolution" (2003) 36 UBC L Rev 231 at 243 [Footnotes omitted] [emphasis in original] [Sankoff, "Constitutional Exemptions"].

27 The history from 1993 to 2000 is reviewed in Sankoff, supra note 25.

282008 SCC 6, [2008] 1 SCR 96 [Ferguson, cited to SCC].

$29 \quad$ Ibid at para 55.

30 As she wrote, ibid at para 74, "constitutional exemptions should not be recognized as a remedy for cruel and unusual punishment ... If a law providing for a mandatory minimum sentence is found to violate the Charter, it should be declared inconsistent with the Charter and hence of no force and effect."

31 These are not the only decisions on point, though they are probably the most significant. Also worthy of note are $R v$ Lewis, 2012 ONCJ 413 , where Bellefontaine J of the Ontario Court of Justice struck down section 99(2) of the Criminal Code, which imposed a minimum three-year period of imprisonment for firearms trafficking. The decision is less significant than the cases presented here because it proceeds on the basis of standard "reasonable hypothetical" analysis, simply concluding that the three year period had the potential to be grossly disproportionate in relation to youthful individuals with no prior record. In other words, it does not really address the problem being focused upon in this article. Another decision of interest is $R v$ Mohla 2012 ONSC 30 [Mohla], which addresses Crown discretion in the sentencing phase of trial, discussed below.

\section{ONSC 4874 (CanLII) [Nur].}

33 In addition to the matters discussed below, the accused challenged the provision on the ground that it discriminated against blacks and violated section 15, and on the ground that the "gap" between the punishment available where a person was prosecuted on summary conviction (a maximum of one year) and that available where the prosecution was on indictment (a minimum of three years) was arbitrary and contrary to section 7. Both of these challenges were dismissed, ibid at paras 74-82 (for the section 15 argument),
121-143 (for the section 7 argument).

34 Nur, supra note 32 at para 96.

35 Ibid at paras 101-103. To be clear, Code J found that the presented situations were all "reasonable" hypothetical scenarios, in accordance with the Supreme Court's decision in Morrisey, supra note 17.

$36 \quad$ Ibid at para 109.

$37 \quad$ Ibid at para 117.

$38 \quad$ Ibid at para 119.

392012 ONSC 602 (CanLII)) [Smickle].

40 See, for example, Adrian Humphreys, "Tory Gun Laws in Jeopardy after Judge Rejects 'Outrageous' Mandatory Sentence”, National Post (12 February 2012), accessible at http://news.nationalpost. com/2012/02/13/judge-rejects-outrageous-unconstitutional-mandatory-gun-sentence/.

41 Nur, note 32 at para 107 [footnotes omitted].

42 The case is, of course, being appealed, as is Nur. At the time of publication, neither case has been heard by the Ontario Court of Appeal.

43 Berger, note 24 at 112 [emphasis in original]. See, in a similar vein, Allan Manson, "Motivation, the Supreme Court and Mandatory Sentencing for Murder" (2001) 39 CR (5th) 65 at 71.

44 Nur, supra note 33 at para 118. See also Mohla, supra note 31 (Crown discretion to serve Notice pursuant to section 727(1) to obtain minimum sentence for repeat impaired driving offenders circumscribed by Crown policy manual).

45 Manson, supra note 3 at $173-175$, calls this methodological approach a distraction that has truncated section 12's potential for growth.

46 See for example, Roach, supra note 3; Berger, supra note 24; Athar Malik, "Mandatory Minimum Sentences: Shackling Judicial Discretion for Justice or Political Expediency" (2007) 53 Crim LQ 236 [Malik].

47 This approach would be inevitable because the analysis would separate section 12 claims into those which are "likely" to arise, and whether the statute is satisfactory in most instances. Any case that fell outside of the "likely" scenario would be treated as a challenge to the Crown's discretion in charging by indictment.

48 [1992] 1 SCR 91 at para 8 [Bain].

492010 ONCA 830 (CanLII) (2010) 264 CCC (3d) 423 (Ont CA), leave to appeal granted, 2011 CanLII 65594 (SCC).

$50 \quad$ Ibid note 49 at para 100.

51 Nur, supra note 32 at para 117. See also the comments of Molloy J. on this point in Smickle, supra note 39 at para 107.

$52 \quad 2012$ ONSC 30.

53 Mohla, supra note 31 at paras 11, 17. 
54 There is reason to think the provision might be vulnerable to a proper constitutional attack. Hill J noted, ibid at para 205, that "because the 13+ year gap is such a substantial time period, in the context of an absence of most of the aggravating factors delineated in the Ministry policy, the section 727(1) decision on its face raises the prospect of arbitrary decision-making implicating section 7 of the Charter." The constitutional challenge to the Crown's discretion was rejected, for reasons to be discussed, but this excerpt suggests that a challenge to the legislation itself might bear more fruit.

55 Hill J relied upon the analysis of the Supreme Court in Krieger v Law Society (Alberta), [2002] 2 SCR 372, which held that Crown discretion had to be separated into core and non-essential elements. Actions falling into the first category were extremely difficult to review, Mohla, supra note 31 at paras $156-165$

Mohla supra note 31 at para 164.

Although the Supreme Court of Canada has not definitively pronounced on this subject, the jurisprudence suggests that charging decisions are part of a core prosecutorial discretion. See $R$ $v$ Dudley, 2009 SCC 58, [2009] 3 SCR 570 at paras 65-66, per Charron J for a minority of the Court [the majority did not address this issue]; Smythe $v R$, [1971] SCR 680; $R v$ Laws (1998), 41 OR (3d) 499 (CA).

2011 SCC 34, [2011] 2 SCR 566 at para 52, citing $R v$ Nixon, 2009 ABCA 269 at para 49 [cited to SCC] [footnotes omitted].

59 Unless, of course, the abuse doctrine were radically reconceptualized.

60 Ferguson, supra note 28 at para 57.

61 Lisa Dufraimont, "R. v. Ferguson and the Search for a Coherent Approach to Mandatory Minimum Sentences under Section 12" (2008) 42 Sup Ct L Rev (2d) 459 at 475-476 [Dufraimont], agrees with my suggestion in Sankoff, "Constitutional Exemptions," supra note 26, that reassessing "binding" precedents when faced with sympathetic fact scenarios is "the only real choice," but worries that reconsideration of constitutionality along these lines "represents a more radical challenge to the principle of stare decisis than the Supreme Court appears to have appreciated. More than a passing reference from the Court is needed to ensure that claimants in exceptional cases have a remedy." On this point, I share Berger's view, supra note 24 at 123, that "the [Court's] expectation is explicit and does not require lower court judges to ignore precedent." As Berger points out, Ferguson simply requires us to re-think our understanding of what a particular constitutional precedent actually stands for.

62 On this point, I tend to agree with Dufraimont, supra note 61 at 474, that "offering no remedy to the exceptional section 12 claimant represents the path of least resistance." Berger is more optimistic, noting, supra note 24 at 124, that "the 'sticker shock' of being faced with having to strike down an otherwise fair law because of injustices in a single exceptional case ... [may] spell a retreat from the scrutiny of mandatory minimum sentences," but adds that "judges are not timorous souls." In the end, he predicts that "it is entirely reasonable to anticipate that we will indeed see the kind of judicial intervention in the politics of minimum sentences." Smickle is at least one indication that Berger's optimism is not entirely misplaced.

63 See, for example, $R v$ Hall, 2002 SCC 64 at para 43.

64 Ferguson, supra note 28 at para 73.

65 Dufraimont, supra note 61 at 476 points to some of the same passages, noting that the Court "sends mixed messages about whether section 12 rulings can be reconsidered.” As noted earlier, I do not share this view of the passages, but I do share Dufraimont's implicit observation that the Court's reasoning is flawed so long as it does not apply equally to its general approach to section 12 analysis.

66 Another result McLachlin CJC decried in Ferguson, supra note 28 at para 72 , noting that exemptions "invite[] duplication of effort. The matter of constitutionality would not be resolved once and for all under section 52(1); in every case where a violation is suspected, the accused would be obliged to seek a constitutional exemption." This is exactly what the Court has mandated through its approach to section 12, where every offender who feels aggrieved must bring a separate constitutional challenge against the law.

67 See for example, Baron $v$ Canada (AG) [1993] 1 SCR 416 (absence of discretion to avoid issuing warrant unconstitutional); $R v$ Demers, 2004 SCC 46, [2004] 2 SCR 289 (absence of discretion to allow discharge for mentally unfit defendants who posed no threat unconstitutional).

68 On this point, see also Malik, supra note 46 at 256-257 who recommends an "escape clause" modelled on South Africa's approach to mandatory minimum penalties, allowing judges to impose a different sentence where "substantial and compelling circumstances" exist.

69 The statutory term groups violent offences in which DNA evidence is more likely to be a factor 
than other crimes because of the nature of the activity at issue. See, Criminal Code, s 487.04 .

70 Another example of this type is the "presumptive" weapon prohibition for offenders convicted of certain offences. Section 113 of the Code allows a judge to avoid imposing such an order where there are extraordinary circumstances and the offender needs a firearm for sustenance hunting or the like.

71 This type of challenge would go to the very core of the DNA collection procedure, maintaining that the nature of the search itself, and collection in any case, or some other basic aspect of the scheme violates sections $7 \& 8$ of the Charter.

72 A matter of some importance, for the loss of the primary provision would be likely to jeopardize the legality of all samples collected pursuant to the legislation, putting numerous prosecutions at risk.

73 Since unusual cases would fall to be decided by the discretion, a constitutional challenge based on difficult facts would focus on whether the trial judge erred in the exercise of his or her discretion. Of course, it is also possible that a court would find the legislation to be generally sound, yet find the discretion unduly restrictive. In other words, as constructed, the conclusion would be that the legislation traps too many people in an unconstitutional manner. To remedy this, a court could delete the term "grossly," remove the onus resting on the accused or perhaps find that the balancing criteria for consideration be removed. The primary provisions, however, would still be saved.

74 There is a right of appeal where a DNA collection order is not made, but there is no requirement to provide reasons if the discretion is exercised. The latter requirement is becoming more common however. See, for example, Criminal Code, s 462.37(2.07) (residual discretion to decline to order forfeiture of proceeds of crime where not in the interests of justice; reasons must be provided explaining the exercise of discretion); Criminal Code, s 490.023(3) (exemption from mandatory application of Sex Offender Information Registration Act; reasons must be provided).

Berger, supra note 24 at 121-122. 